\title{
Relation of serum visfatin level and uterine artery Doppler to preeclampsia
}

\author{
Mohamed Abd El-Moety El-Samra ${ }^{1 *}$, Sherif Mansour Aggag ${ }^{2}$
}

\author{
${ }^{1}$ Department of Obstetrics and Gynecology, Alexandria Faculty of Medicine, Egypt \\ ${ }^{2}$ Department of Clinical Pathology, Egyptian Ministry of Health, Alexandria, Egypt
}

Received: 06 November 2017

Accepted: 02 December 2017

\author{
*Correspondence: \\ Dr. Mohamed Abd El-Moety El-Samra, \\ E-mail: melsamra@yahoo.com
}

Copyright: () the author(s), publisher and licensee Medip Academy. This is an open-access article distributed under the terms of the Creative Commons Attribution Non-Commercial License, which permits unrestricted non-commercial use, distribution, and reproduction in any medium, provided the original work is properly cited.

\begin{abstract}
Background: Preeclampsia (PE) is a significant cause of remarkable fetomaternal morbidity and mortality worldwide. Visfatin is $52 \mathrm{KDa}$ novel adipokine, pre B cell colony enhancing factor (PBEF) which could be used as a biochemical marker predictor or a diagnostic tool for preeclampsia. Trans abdominal pulsed Doppler ultrasound (US) monitor the impedance to blood flow in the uterine arteries in pregnant females and those with preeclampsia. Visfatin has been implicated in the pathogenesis of preeclampsia with a limited contradictory. The aim of our study is to monitor the risky pregnant females through Visfatin level and transabdominal pulsed Doppler of the uterine artery.

Methods: Assessment of the serum Visfatin levels in the maternal circulation of preeclamptic pregnant females wether mild or severe, and compared to those in the normal pregnant subjects as control through recruitment of cases of mild PE $(n=40)$, severe PE $(n=40)$, normal pregnant subjects $(n=60)$ in a cross sectional study where the cases were of the patients hospitalized at El Shatby Hospital of Obstetrics and Gynecology, and the control subjects were of referrals to the outpatient departments. Fasting blood samples were drawn, kept at -20 degree centigrades, enzyme linked immune sorbant assay (ELISA) Test was performed on them to determine the Visfatin level and recorded the uterine arteries pulsatility index through transabdominal doppler ultrasound. Lastly, the data were analysed using (F test) ANOVA statistical method.

Results: Amongst the groups, Serum visfatin level was significantly higher in the severe preeclamptic group rather than the normal pregnant group and those with mild preeclampsia $(\mathrm{p}<0.001)$. Uterine artery pulsatility index was significantly higher in the severe preeclamptic group rather than the normal pregnant group and those with mild preeclampsia $(\mathrm{p}<0.001)$.

Conclusions: Severe preeclamptic pregnant females were shown to represent higher circulating visfatin levels as one of the most recent biochemical markers of preeclampsia, higher uterine artery pulsatility index compared to normal pregnant and those with mild preeclamptic groups of women.
\end{abstract}

Keywords: Adipocytokines, Mild preeclampsia, Pregnancy, Severe preeclampsia, Uterine artery Doppler ultrasound, Visfatin

\section{INTRODUCTION}

Preeclampsia is an important cause of fetomaternal morbidity and mortality. It is not only unpredictable in onset and progression, but also has no effective management strategy except termination of pregnancy. ${ }^{1,2}$
Despite the intensive efforts to delineate the pathophysiology of preeclampsia, neither a specific cause nor pathogenesis has been identified. ${ }^{3}$

One of the contributing factors which can play a role in the pathophysiology of preeclampsia is alteration in the 
serum level of adipokines which has been widely pointed out in literature. ${ }^{4-6}$

Visfatin is a novel adipokine mainly secreted by the visceral adipose tissue rather than by the subcutaneous fat. But in pregnancy, also expressed in the placenta and foetal membranes. ${ }^{7,8}$ Its physiological characteristics and activity includes improving glucose tolerance, pre B cell colony enhancing factor (PBEF), having insulinomimetic and immunoregulatory properties. Also, it is a marker of endothelial damage which has a variable effect on vascular tissues which is observed in both early and late onset preeclampsia. ${ }^{9,10}$

There is evidence that severe early onset preeclampsia is due to impaired placental perfusion manifested with increased pulsatility index in the uterine arteries. ${ }^{11-13}$ Where in late preeclampsia the main pathophysiological processes resemble those of the metabolic syndrome with increased insulin resistance. ${ }^{14-16}$

In order to verify that circulating level of visfatin and uterine artery pulsatility index are altered in women with preeclampsia, this study was carried out to determine the quality of this alteration and comparing it with those of the normal pregnant control subjects.

\section{METHODS}

Th This cross sectional study has been done on a total number of 140 pregnant females from whom, 80 participants were cases of preeclamptic disorder divided into (mild 40 and severe 40) and 60 were normal pregnant women as control.

All participants signed informed written consents after being matched and balanced for parity (all are primigravida), and gestational age (28-30 weeks) in compliance with the definition of preeclampsia.

Exclusion criteria were gestational diabetes, infectious diseases, premature rupture of membrane, any other medical disease and being in the labour phase.
The pregnant control subjects were healthy reproductive with non of a forementioned exclusion criteria from those referring to the outpatient department clinics in the period from December 2010 to February 2012.The pregnant preeclamptic cases were recruited from patients hospitalized at El Shatby Obstetrics and Gynecology Hospital. The study was approved by the Hospital ethical committee.

Collected fasting blood samples from subjects were preserved in aliquot at -20 degree centigrades then Enzyme Linked Immune Sorbant Assay (ELISA) was applied to determine visfatin levels (ng/ml).

The assay was conducted using Biovision Human Visfatin ELISA kit and according to the instructions of the manufacturer with detection limit of $0.1 \mathrm{ng} / \mathrm{ml}$, the kit measurability for visfatin ranged from $0.125 \mathrm{ng} / \mathrm{ml}$ to 8 $\mathrm{ng} / \mathrm{ml}$

\section{Statistical analysis}

The data were analysed statistically using SPSS software version 18 with probability value of significance less than 0.05. In all the participants, we measured the uterine artery pulsatility index through transabdominal pulsed Doppler and recorded the mean value then $F$ test (ANOVA) was done to compare the results between the mild, severe preeclamptic groups and the control group.

\section{RESULTS}

The age of participant ranged from 20 to 42 years, with mean of $29 \pm 2.7$ years. In 40 patients with mild preeclampsia, the mean age was $30.0 \pm 4.8$ years $(95 \% \mathrm{CI}$ of the mean 27.7-32.4 years), in 40 patients with severe preeclampsia it the mean age was $29.0 \pm 4.6$ years $(95 \% \mathrm{CI}$ of the mean 26.9-31.0 years), while in 60 control patients the mean age was $28.0 \pm 3.5$ years $(95 \%$ CI of the mean 26.8-29.5 years).

The age among the three studied groups was not statistically significantly different $(\mathrm{p}=0.069)$ (Table 1$)$.

Table 1: The characteristic features of enrolled subjects across groups regarding the age.

\begin{tabular}{|c|c|c|c|c|c|c|}
\hline & \multirow{2}{*}{ Number } & \multirow{2}{*}{ Mean } & \multirow{2}{*}{ SD } & \multicolumn{2}{|c|}{$95 \%$ confidence interval } & \multirow{2}{*}{ P value } \\
\hline & & & & Lower & Upper & \\
\hline Control & 60 & 28.0 & 3.5 & 26.8 & 29.5 & \multirow{3}{*}{0.069} \\
\hline Mild PE & 40 & 30.0 & 4.8 & 27.7 & 32.4 & \\
\hline Severe PE & 40 & 29.0 & 4.6 & 26.9 & 31 & \\
\hline
\end{tabular}

The mean serum level of Visfatin for pregnant control group was $2.8 \pm 6.76 \mathrm{ng} / \mathrm{ml}(95 \% \mathrm{CI}$ of the mean $2.04-3.56$ $\mathrm{ng} / \mathrm{ml}$ ), in patients with mild preeclampsia it was $2.67 \pm 0.86 \mathrm{ng} / \mathrm{ml}(95 \% \mathrm{CI}$ of the mean $1.81-.53 \mathrm{ng} / \mathrm{ml})$, while in patients with severe preeclampsia it was $8.1 \pm 0.6$ $\mathrm{ng} / \mathrm{ml}$ (95\% CI of the mean 7.5-8.7 ng/ml). Serum Visfatin level in severe preeclamptic females group was statistically significantly higher when compared with 
those with mild preeclamptic or the control groups $(\mathrm{p}<0.001)$. No statistically significant difference was found between patients with mild preeclampsia compared with controls (Table 2).

Table 2: The mean visfatin level in all groups.

\begin{tabular}{|c|c|c|c|c|c|c|}
\hline & \multirow{2}{*}{ Number } & \multirow{2}{*}{ Mean } & \multirow{2}{*}{ SD } & \multicolumn{2}{|c|}{$95 \%$ Confidence Interval } & \multirow{2}{*}{ P value } \\
\hline & & & & Lower & Upper & \\
\hline Control & 60 & 2.8 & 0.76 & 2.04 & 3.56 & \multirow{3}{*}{$<0.001^{*}$} \\
\hline Mild PE & 40 & 2.67 & 0.86 & 1.81 & 3.53 & \\
\hline Severe PE & 40 & 8.1 & 0.6 & 7.5 & 8.7 & \\
\hline
\end{tabular}

$\mathrm{p}: \mathrm{p}$ value for $\mathrm{F}$ test (ANOVA) for comparing between the different studied groups; *: Statistically significant at $\mathrm{p} \leq 0.05$

The mean uterine artery pulsatility index is significantly higher in the severe preeclamptic groups $(1.96 \pm 0.44)$ compared to mild preeclamptic $(1.68 \pm 0.33)$ or the control groups $(1.65 \pm 0.3)(\mathrm{p}<0.001)$. No statistically significant difference was found between patients with mild preeclampsia compared with controls (Table 3).

Table 3: The mean uterine artery Pulsatility Index (PI) in all groups.

\begin{tabular}{|c|c|c|c|c|}
\hline & $\begin{array}{l}\text { Control } \\
(n=60)\end{array}$ & $\begin{array}{l}\text { Mild PE } \\
(n=40)\end{array}$ & $\begin{array}{l}\text { Severe PE } \\
(n=40)\end{array}$ & P value \\
\hline Mean & 1.65 & 1.68 & 1.96 & \multirow{2}{*}{$<0.001^{*}$} \\
\hline SD. & 0.3 & 0.33 & 0.44 & \\
\hline
\end{tabular}

$\mathrm{p}$ : $\mathrm{p}$ value for $\mathrm{F}$ test (ANOVA) for comparing between the three studied groups *: Statistically significant at $\mathrm{p} \leq 0.05$

\section{DISCUSSION}

In this study, the data obtained supported the influence of preeclampsia severity on the circulating Visfatin level, uterine artery pulsatility index findings demonstrated increased upregulation of the Visfatin level and highly increased impedance to blood flow in case of severe preeclampsia rather than the mild preeclamptic or the control groups as expressed in the placenta and foetal membranes.

The results of study in pregnant females with established preeclampsia reported that the levels of Visfatin level were higher in those with Doppler evidence of increased rather than normal impedance to flow in the uterine arteries.

In agreement with our findings, the studies of Fasshauer et al, Ferreira et al denoting increased level of Visfatin in preeclamptic pregnant women but not divided them into mild and severe preeclamptic groups and that done by Tavana et al which did not include the relative benefit of Doppler ultrasound in these cases. ${ }^{4,17,18}$

In contrast to our findings, Wensheng et al, which reported a decrease in serum Visfatin level in preeclamptic pregnant women compared to control. ${ }^{5}$

\section{ACKNOWLEDGMENTS}

The authors express their heartfelt gratitude to the staff and members of the Department of Obstetrics and Gynecology, and Alexandria Faculty of Medicine, and Department of Clinical Pathology, Egyptian Ministry of Health, Alexandria, Egypt.

\section{Funding: No funding sources}

Conflict of interest: None declared

Ethical approval: The study was approved by the IRB, Faculty of Medicine, University of Alexanrdia

\section{REFERENCES}

1. Redman CW, Sargent IL: Latest advances in understanding preeclampsia. Science. 2005;308:1592-4.

2. Sibai B, Dekker G, Kupferminc M. Pre-eclampsia. Lancet. 2005;365:785-99.

3. Taylor RN. Immunology of preeclampsia. Am J Reo Immuonol. 1997;37:79-88.

4. Fasshauer M, Waldeyer T, Seeger J, Schrey S, Ebert $\mathrm{T}$ et al. Serum levels of the adipokine visfatin are increased in preeclampsia. Clin Endocrinol. 2008;69(1):69-73.

5. Wensheng $\mathrm{Hu}$, Zhengping W, Hanzhi W, Hefeng H, Minyue D. Serum visfatin levels in late pregnancy and preeclampsia. Acta Obstet Gynecol. 2008;87:413-8.

6. Poston L. Leptin and preeclampsia. Semin Report Med. 2002;20:131-8.

7. Ma Y, Cheng Y, Wang J, Cheng H, Zhou S, Li X. The changes of visfatin in serum and its expression in fat and placental tissue in pregnant women with gestational diabetes. Diabetes Res Clin Pract. 2010;90:60-5.

8. Jia SH, LI Y, Parodo J, Kampus A, Fan L, Rotstein $\mathrm{OD}$, et al. Pre-B cell colony enhancing factor inhibit neutrophil apoptosis in experimental inflammation and clinical sepsis. J Clin Invest. 2004;113:1318-27.

9. Marvin KW, Keelan JA, Eykholt RL, Sato TA, Mitchell MD. Use of cDNA arrays to generate differential expression profiles for inflammatory 
genes in human gestational membranes delivered at term and preterm. Mol Hum Reprod. 2002;8:399408.

10. Ognjanovic S, Bryant-Greenwood GD. Pre-B-cell colony-enhancing factor, a novel cytokine of human fetal membranes. Am J Obstet Gynecol. 2002; 187:1051-8.

11. Brosens I, Pijnenborg R, Vercruysse L, Romero R. The Great Obstetrical Syndromes are associated with disorders of deep placentation. Am J Obstet Gynecol. 2011;204:193-201.

12. Yu CKH, Smith GCS, Papageorghiou AT, Cacho AM, Nicolaides KH. An integrated model for the prediction of preeclampsia using maternal factors and uterine artery Doppler velocimetry in unselected low risk women. Am J Obstet Gynecol. 2005;193:429-436.

13. Plasencia W, Maiz N, Bonino S, Kaihura C, Nicolaides KH. Uterine artery Doppler at 110 to 136 weeks in the prediction of preeclampsia. Ultrasound Obstet Gynecol. 2007;30:742-9.

14. Lorentzen B, Birkeland KI, Endresen MJ, Henriksen T. Glucose intolerance in women with preeclampsia. Acta Obstet Gynecol Scand. 1998;77:22-7.
15. Vatten LJ, Skjaerven R. Is pre-eclampsia more than one disease? BJOG. 2004;111:298-302.

16. D'Anna R, Baviera G, Corrado F, Giordano D, De Vivo A, Nicocia $G$ et al. Adiponectin and insulin resistance in early- and late-onset pre-eclampsia. BJOG. 2006;113:1264-9.

17. Ferreira AFA, Rezende JC, Decassia R, Oliveira C, Akolekar R, Nicolaides KH. Maternal Serum Visfatin at 11-13 weeks gestation in preeclampsia. J Human Hypertens. 2013;27:261-4.

18. Tavana Z, Madadi G, Zolghadri J. The relationship between maternal serum visfatin level and hypertensive disorders of pregnancy. Internet $\mathbf{J}$ Gynecol Obstet. 2010;15(1):11166.

Cite this article as: El-Samra MAE, Aggag SM. Relation of serum visfatin level and uterine artery Doppler to preeclampsia. Int J Reprod Contracept Obstet Gynecol 2018;7:48-51. 